\title{
New turtle egg fossil from the Upper Cretaceous of the Laiyang Basin, Shandong Province, China
}

\author{
QIANG WANG ${ }^{1}$, XIAOLIN WANG ${ }^{1}$, ZIKUI ZHAO ${ }^{1}$, JIALIANG ZHANG ${ }^{1,2}$ and SHUNXING JIANG ${ }^{1,2}$ \\ ${ }^{1}$ Key Laboratory of Vertebrate Evolution and Human Origin of Chinese Academy of Sciences, \\ Institute of Vertebrate Paleontology and Paleoanthropology, Chinese Academy of Sciences, Beijing, 100044, China \\ ${ }^{2}$ University of Chinese Academy of Sciences, Beijing, 100049, China
}

Manuscript received on June 11, 2012; accepted for publication on November 23, 2012

\begin{abstract}
A new type of turtle egg fossil was established: Emydoolithus laiyangensis oogen. et oosp. nov.. Based on its elliptical morphological shape, rigid eggshells, and eggshell characteristics, it is different from other types of round chelonian egg fossils. It is the second chelonian egg fossil found in Cretaceous in China. This discovery shows the Laiyang ecosystem in Late Cretaceous is more diversified than previously thought.
\end{abstract}

Key words: Turtle egg fossil, Jingangkou Formation, Late Cretaceous, Laiyang Basin, Shandong Province.

\section{INTRODUCTION}

Turtle egg fossils are very rare. Even though they are found from the Jurassic to the Tertiary age, turtle eggs are known only from a few Cretaceous deposits, from localities in China (Fang et al. 2003, Jackson et al. 2008), Mongolia (Mikhailov et al. 1994), Japan (Isaji et al. 2006), India (Mohabey 1998), Brazil (Azevedo et al. 2000), and the United States (Hirsch 1996, Bray and Hirsch 1998, Kohring, 1999). A review of previous work on the turtle egg fossils has been done by Jackson et al. (2008).

Testudoolithus jiangi, which was found in Tiantai, Zhejiang Province (Fang et al. 2003, Jackson et al. 2008), is the only valid turtle egg fossil found in China. Although the egg fossils found in Changtu, Liaoning Province, in 1921 were originally thought to be turtle eggs (Yabe

Correspondence to: Xiaolin Wang

E-mail:wangxiaolin@ivpp.ac.cn and Ozaki 1929), they were later recognized as dinosaur eggs based on their macrostructure characteristics (Chow 1954). Recently, we have restudied the macrostructure and microstructure of these eggs found in Changtu (housed at the Dalian Nature History Museum) and confirmed they are indeed dinosaur eggs (to be reported in another paper). During an excavation in the Laiyang Basin, Shandong Province in 2010 (Fig. 1A), we found a new turtle egg in the first excavation site where the famous Tsintaosaurus was found (Fig. 1B). This is the second valid turtle egg fossil found in China.

\section{GEOLOGICAL SETTING}

Laiyang Basin, in Shandong Province, is a very important basin in China, rich in fossil plants, insects, and vertebrates, especially dinosaurs and their eggs. The terrestrial Cretaceous strata in this basin consist of the Laiyang Group, Qingshan Group and 

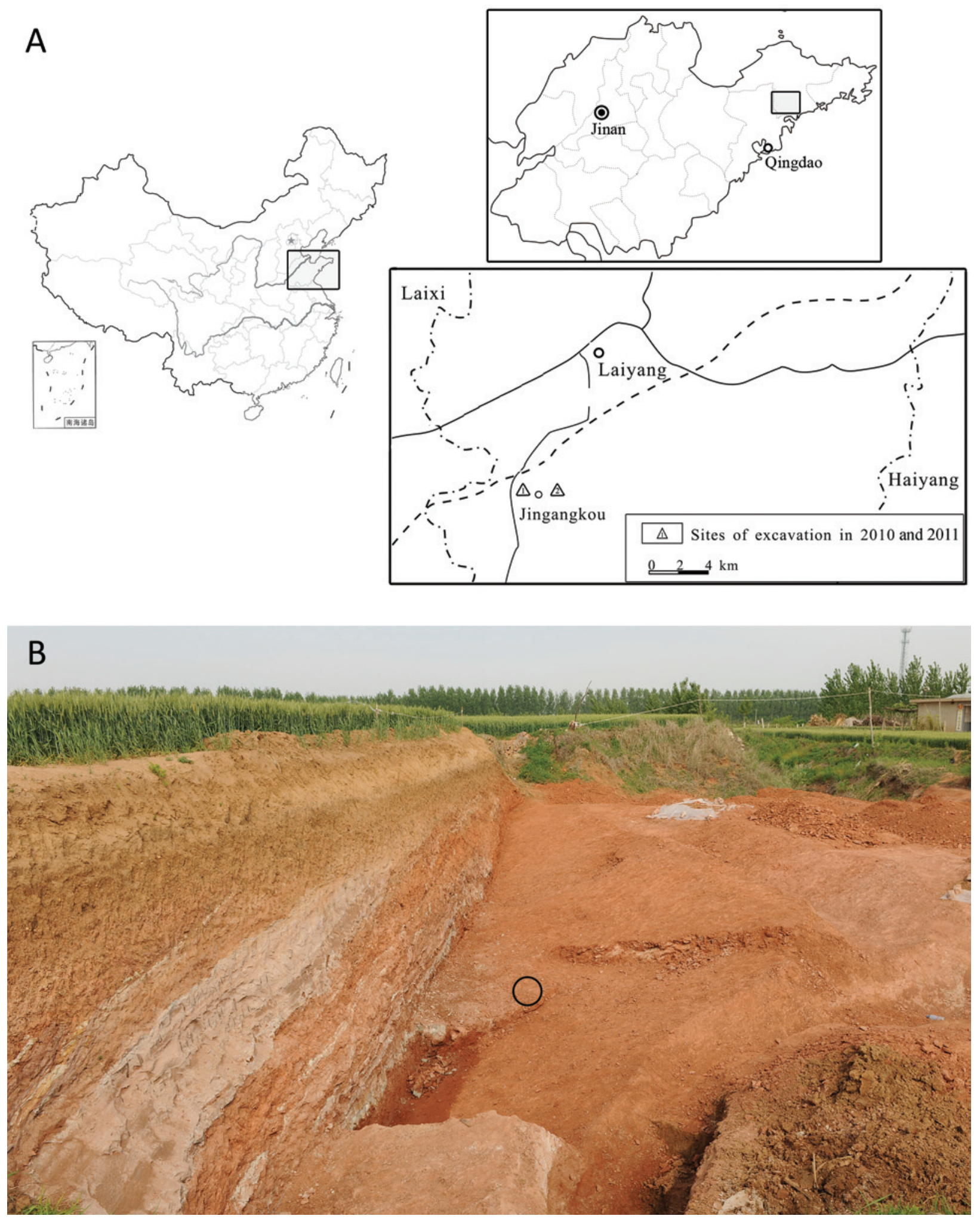

Fig. 1 - Locality of the turtle egg fossil in the Laiyang Basin, Shandong Province.

A. sketch map of excavation sites in 2010 and 2011; B. the first excavation site showing the turtle egg position (the black circle). 
Wangshi Group from the Early Cretaceous to Late Cretaceous, in ascending order (Wang et al. 2010). The Early Cretaceous Laiyang Group consists of fluvial and lacustrine sediments and the Qingshan Group consists mainly of intermediate or acidic volcanic rocks and pyroclastic rocks interbeded with sedimentary rocks (Liu et al. 2011). The Late Cretaceous Wangshi Group which consists of the Xingezhuang Formation, Jiangjunding Formation, Jingangkou Formation, and Changwangpu Formation (Hu et al. 2001), is mainly deposits of alluvial fan, mudflow and braided channel in the lower part, shallow lacustrine deposits and rhythmic fluvial sediments of mudstone, siltstone, sandstone or soils in the middle part, and rhythmic depositions of silty-muddy conglomerate, sandstone and siltstone of mudflow, braided-channel and flooding plain facies (Liu et al. 2011).

There are the famous Late Cretaceous hadrosaurid fauna represented by Tsintaosaurus and Tanius, and the Laiyang dinosaur egg fauna represented by elongatoolithids and ovaloolithids in the Wangshi Group (Fig. 2) (Wang et al. 2010, 2012). Up to now, over ten genera and species of dinosaurs, four oofamilies, five oogenera and eleven oospecies of dinosaur eggs, one species of turtle have been reported from the Wangshi Group of the Laiyang Basin. All fossils were found in the Jiangjunding and Jingangkou formations, belonging to the middle part of the Wangshi Group (Wang et al. 2012). In 2010 and 2011 excavations, we found some dinosaurs, dinosaur eggs, turtle, turtle egg, crocodile teeth, gastropods, and plant fragments in two localities (Fig. 1A). Here, we report on the turtle egg found from the Upper Cretaceous Jingangkou Formation in Laiyang in 2010. This is the second turtle egg ever found in China.

\section{MATERIALS AND METHODS}

The specimen studied in this paper is a complete egg, found during an excavation in 2010 in the Jingangkou Formation (Upper Cretaceous) in

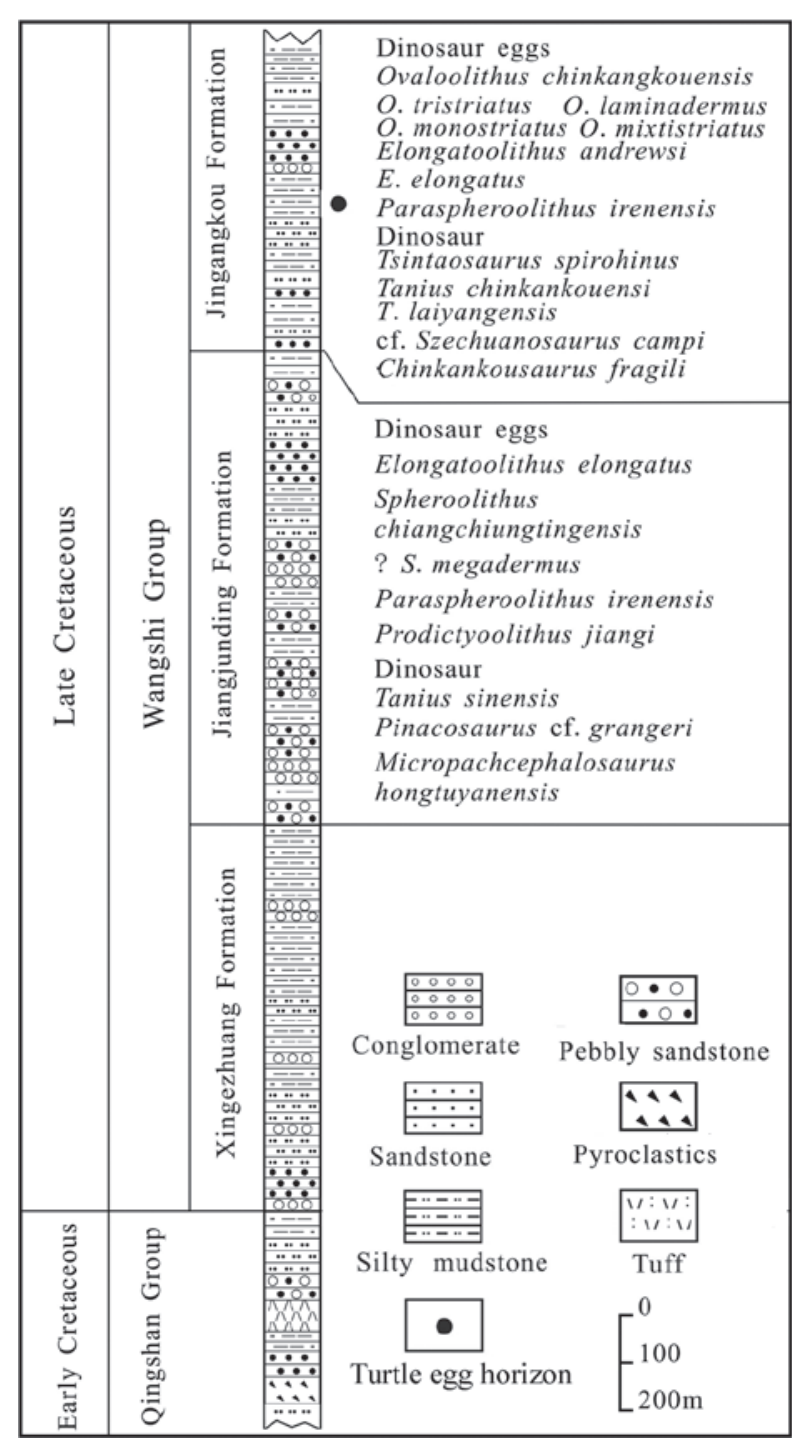

Fig. 2 - stratigraphy showing dinosaurs, dinosaur eggs and turtle egg of the Laiyang Basin, Shandong Province (Modified from Wang et al. 2012).

Laiyang Basin (Fig. 2). We used calipers to measure the morphological data of the egg. We took six eggshell samples from the egg to study its eggshell microstructure. Four of them were used to make radial and tangential section with cutting system (EXAKT 300CP and EXAKT 400CS). The other two were used to observe the radial sections with SEM (S-3700N). These two specimens were embedded and polished, and etched 30 seconds in $1 \% \mathrm{HCl}$ solution, then gilded and observed in operating voltage $10 \mathrm{Kv}$. All the processes were carried out at 

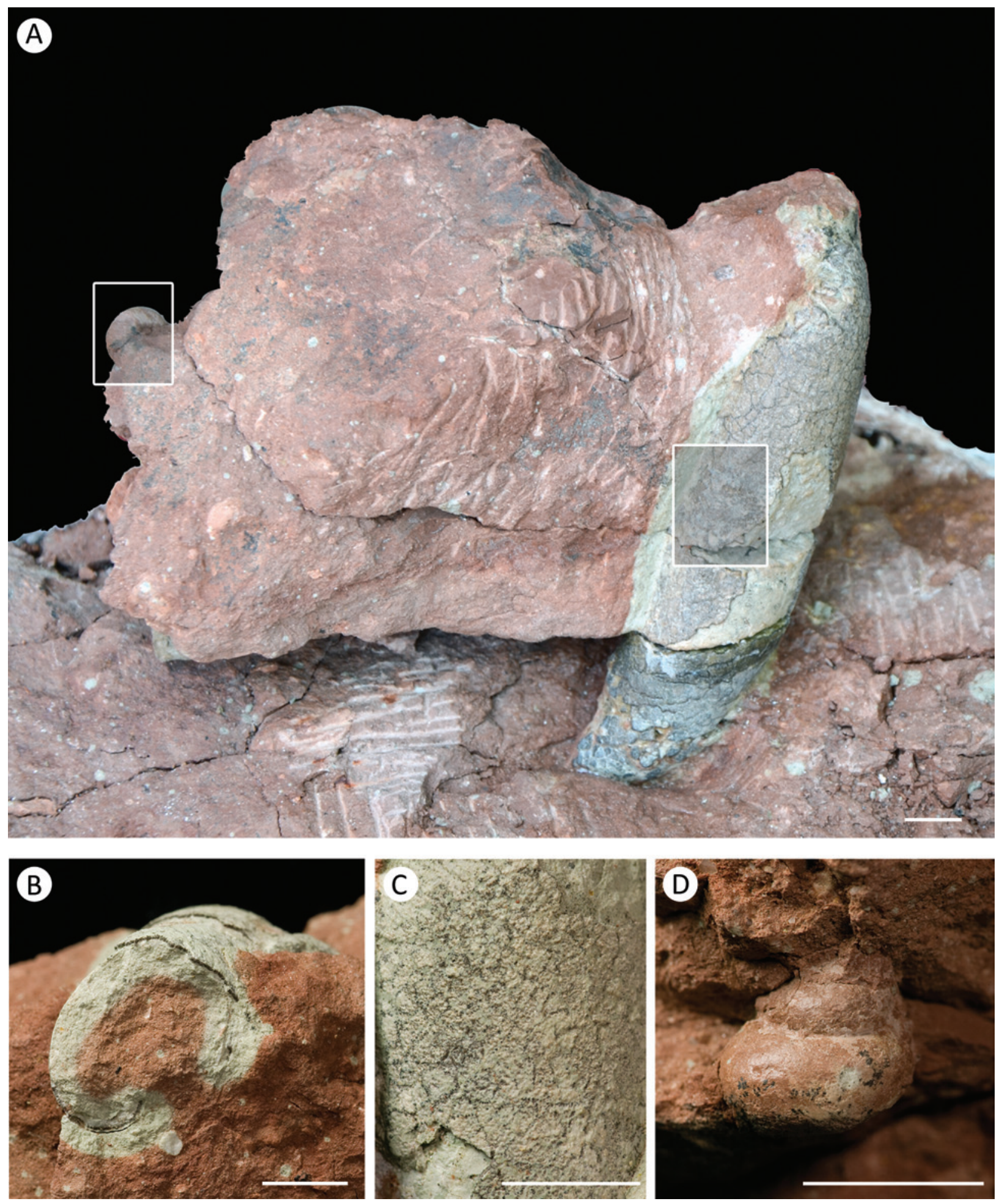

Fig. 3 - Holotype of Emydoolithus laiyangensis oogen. et oosp. nov.

A. the whole fossil specimen (IVPP V18544), showing the egg and a gastropod (in the white frame); B. top view of the egg, showing the interior filled by muddy siltstone; C. enlarged part of the egg (the white frame in A) showing small pieces of eggshell; D. the gastropod near the egg (the one in the white frame in A) Scale bars $=1 \mathrm{~cm}$. 
Key Laboratory of Vertebrate Evolution and Human Origin of Chinese Academy of Sciences, Institute of Vertebrate Paleontology and Paleoanthropology, Chinese Academy of Sciences.

\section{SYSTEMATIC PALEONTOLOGY}

Oofamily TESTUDOOLITHIDAE Hirsch, 1996 Oogenus EMYDOOLITHUS oogen. nov.

Etymology Emyd-, Greek word, means a freshwater turtle, - oolithus, a form genus suffix for fossil eggs. Diagnosis Same as for type and only known oospecies.

\section{Oospecies EMYDOOLITHUS}

LAIYANGENSIS oogen. et oosp. nov.

Etymology after Laiyang City, where the fossil was found.

Holotype A nearly complete symmetrical elongate elliptical egg, housed at the Institute of Vertebrate Paleontology and Paleoanthropology of the Chinese Academy of Sciences, Beijing, China (IVPP V18544) (Fig. 3A).

Locality and horizon Jingangkou, Laiyang, Shandong Province; Jingangkou Formation; Wangshi Group; Late Cretaceous

Diagnosis Symmetrical elongate elliptical, the polar axis is $9.1 \mathrm{~cm}$, the equatorial diameter is 2.2 $-2.5 \mathrm{~cm}$, and shape index is 27.4. The thickness of the hard calcareous eggshell is $400-500 \mu \mathrm{m}$, the width of the shell units is $100-200 \mu \mathrm{m}$, and shell unit height-to-width ratio is $2: 1-5: 1,50-60$ shell units per square millimeter.

\section{DESCRIPTION}

IVPP V18544 is a complete symmetrical elongate elliptical egg (Fig. 3A), with a hard calcareous eggshell (Fig. 3B, C). Because an extrusion, eggshell was broken in small pieces (Fig. 3C). The egg was preserved in the red pebbly muddy siltstone, and a gastropod fossil was found nearby (Fig. 3A, D).
The polar axis of the egg is $9.1 \mathrm{~cm}$; the equatorial diameter is $2.2-2.5 \mathrm{~cm}$. Shape index (the equatorial diameter/polar axis $\times 100 \%$ ) is 27.4 . Thickness of eggshell is $400-500 \mu \mathrm{m}$. The width of the eggshell units is $100-200 \mu \mathrm{m}$, and the ratio of shell unit height-to-width is $2: 1-5: 1$. The eggshell is composed of tightly arranged columnar eggshell units (Fig. 4A, B), with a clear boundary between eggshell units (Fig. 4B, C, D). Nuclei center of eggshell units is not in the same horizontal (Fig. 4B). There is actinomorphic acicular aragonite toward inner surface of eggshell in the lower part of eggshell units (Fig. 4B, C).

In tangential section through the lower part of eggshell, irregular shape eggshell units are tightly arranged with a clear boundary between eggshell units (Fig. 4E, F). There are 50 -60 eggshell units per square millimeter. Within the eggshell units, there are one or more crystal particles (Fig. 4E, F), which are also found in the living turtle Podocnemis unifilis (see Schleich and Kästle 1988, Fig. 9).

\section{COMPARISONS AND CONCLUSIONS}

Emydoolithus laiyangensis is a turtle egg, because that only chelonian eggs have aragonite eggshell unit characteristics (Hirsch 1983). Hirsch (1996) established two parataxonomic oofamilies of chelonian eggs: Testudoolithidae and Testudoflexoolithidae with the oogenera Testudoolithus and Testudoflexoolithus and three oospecies. Eggshell units are generally wider than high and loosely abutting in soft shell in testudoflexoolithids. Eggshell units are higher than wide, and crystals of adjacent units interlock with each other in rigid eggshell in testudoolithids.

In comparison, Emydoolithus laiyangensis is similar to Testudoolithus jiangi in the thickness of eggshell and the height-to-width ratio of the eggshell unit (Table I). However, elliptical morphological shape of Emydoolithus laiyangensis is different from other round shape turtle eggs (Table I). 

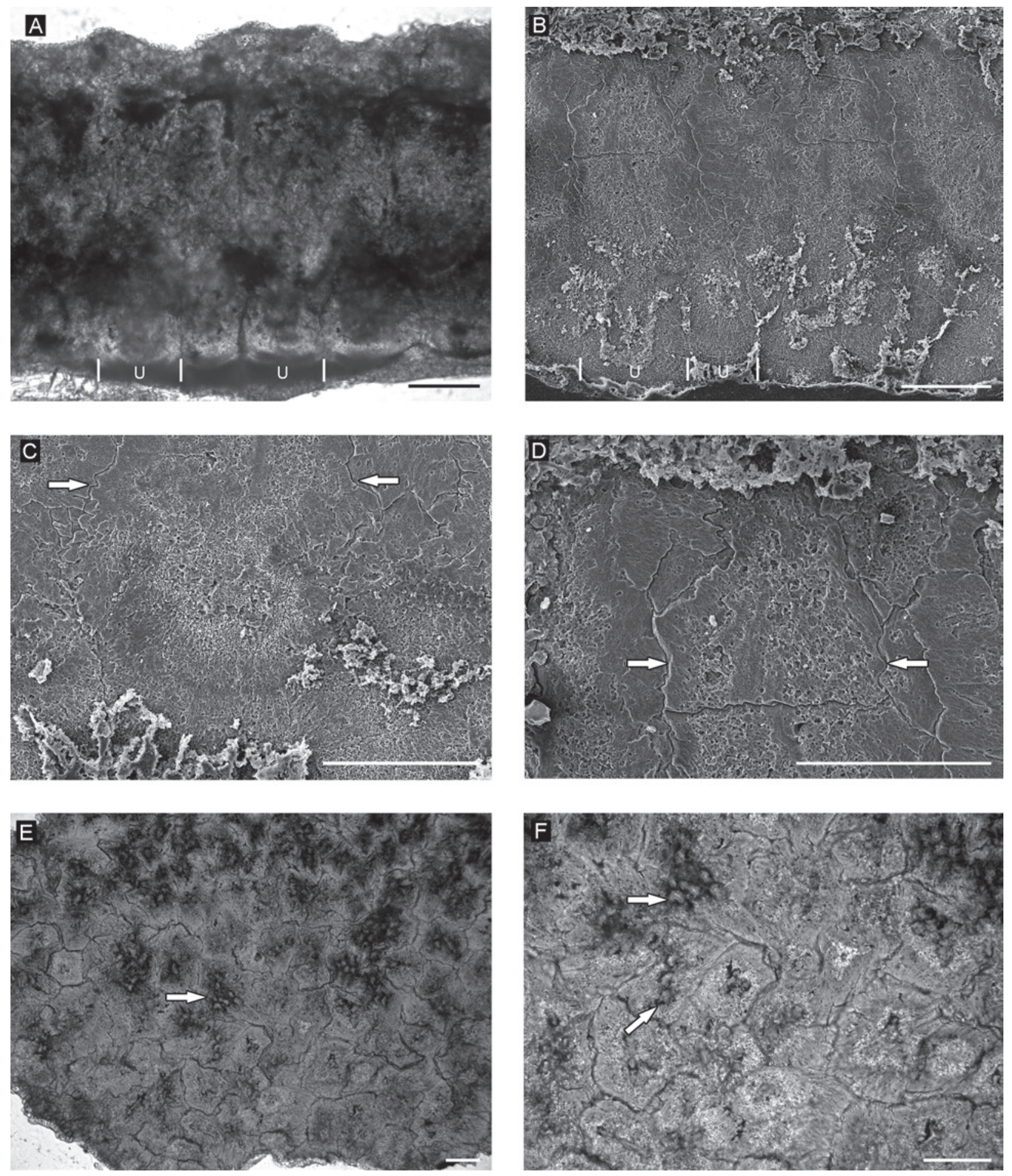

Fig. 4 - Eggshell microstructure of Emydoolithus laiyangensis oogen. et oosp. nov.

A, radial section of eggshell (polarizing microscope); B - D, radial section of eggshell (SEM), C, enlarged lower part of the eggshell unit (SEM), showing aragonite ultrastructure, D, enlarged upper part of the eggshell unit (SEM), showing clear boundary of eggshell units; E - F, tangential section through the lower part of eggshell, E, showing tightly arranged eggshell units, F, enlarged part of $\mathbf{E}$, showing crystal particles (white arrows) in eggshell units, Scale bars $=100 \mu \mathrm{m}$, u: eggshell unit, the white arrows indicating the boundary of eggshell units in $\mathbf{C}$ and $\mathbf{D}$. 
Thus, it represents a new type of turtle egg fossils, so we establish a new oogenus of chelonian eggs: Emydoolithus oogen. nov. with a new oospecies: Emydoolithus laiyangensis oogen. et oosp. nov..

Crystal particles in eggshell microstructure of Emydoolithus laiyangensis is more likely the living turtle Podocnemis unifilisi eggshell microstructure, and many living turtle eggs are symmetrically elliptical like E. laiyangensis. So it is maybe that E. laiyangensis belong to an emydid turtle. Even though, there is one turtle fossil species? Glyptops sp. (Chow 1954) found in the same locality in Laiyang. We also found many turtle carapace and plastron fragments at two sites in 2010 and 2011 excavations. But, we are still not sure the exactly turtle species to which of the fossil egg belongs.

TABLE I

Comparison of chelonian eggs described here and other rigid-shell fossil turtle eggs and turtle egg ootaxa, arranged in chronological order (modified from Jackson et al. 2008 Table I).

\begin{tabular}{|c|c|c|c|c|c|c|c|c|}
\hline Ootaxon & Age & Location & $\begin{array}{c}\text { Shell } \\
\text { morphotype/ } \\
\text { egg shape }\end{array}$ & $\begin{array}{c}\text { Egg size } \\
(\mathrm{mm})\end{array}$ & $\begin{array}{l}\text { Shell unit } \\
\text { height-to- } \\
\text { width ratio }\end{array}$ & $\begin{array}{c}\text { Shell } \\
\text { thickness } \\
(\mu \mathrm{m})\end{array}$ & Shell units & References \\
\hline $\begin{array}{l}\text { Testudoolithus } \\
\text { hirschi }\end{array}$ & Jurassic & Portugal & Rigid & $?$ & $1: 3$ & 150 & Parallel & Kohring (1999) \\
\hline Unnamed & $\begin{array}{c}\text { Early } \\
\text { Cretaceous }\end{array}$ & Japan & $\begin{array}{l}\text { Rigid/round or } \\
\text { slightly elliptical }\end{array}$ & $25-27.5$ & $8: 5-2: 1^{*}$ & $\begin{array}{c}200-250 \\
\quad \text { or } \\
400-430\end{array}$ & Parallel* & Isaji et al. (2006) \\
\hline $\begin{array}{l}\text { Emydoolithus } \\
\text { laiyangensis }\end{array}$ & $\begin{array}{c}\text { Late } \\
\text { Cretaceous }\end{array}$ & China & $\begin{array}{l}\text { Rigid/ } \\
\text { elliptical }\end{array}$ & $25 \times 91$ & $2: 1-5: 1$ & $400-500$ & Parallel & This paper \\
\hline $\begin{array}{l}\text { Testudoolithus } \\
\text { jiangi }\end{array}$ & Cretaceous & China & Rigid/round & $42 \times 45$ & $2: 1-5: 2$ & $500-700$ & Parallel & $\begin{array}{c}\text { Fang et al. (2003), } \\
\text { Jackson et al. } \\
(2008)\end{array}$ \\
\hline $\begin{array}{l}\text { Testudinovum } \\
\text { (egg containing } \\
\text { embryo) }\end{array}$ & Cretaceous & Mongolia & Rigid/round & $35 \times 40$ & $?$ & $\begin{array}{c}180(1991) \\
300-400 \\
(1994)\end{array}$ & Parallel & $\begin{array}{l}\text { Mikhailov (1991, } \\
\text { 1997), Mikhailov et } \\
\text { al. (1994) }\end{array}$ \\
\hline $\begin{array}{l}\text { Unnamed (egg } \\
\text { containing } \\
\text { embryo) }\end{array}$ & Cretaceous & USA & $\begin{array}{l}\text { Rigid/ } \\
\text { slightly elliptical }\end{array}$ & $30 \times 40$ & $?$ & 676 & $\begin{array}{c}\text { Slightly flared } \\
\text { domed }\end{array}$ & $\begin{array}{c}\text { Jackson et al. } \\
\quad(2002)\end{array}$ \\
\hline $\begin{array}{l}\text { Testudoolithus } \\
\text { rigidus }\end{array}$ & $\begin{array}{l}\text { Cretaceous- } \\
\text { Pliocene }\end{array}$ & $\begin{array}{l}\text { Various } \\
\text { location }\end{array}$ & $\begin{array}{l}\text { Rigid/ } \\
\text { round }\end{array}$ & $42 \times 47$ & $2: 1$ & $220-250$ & Parallel & $\begin{array}{l}\text { Hirsch and Bray, } \\
\text { (1988), Hirsch } \\
\text { (1996), Kohring } \\
\text { (1999) }\end{array}$ \\
\hline $\begin{array}{l}\text { Haininchelys } \\
\text { curiosa }\end{array}$ & Paleocene & Germany & $\begin{array}{l}\text { Rigid/ } \\
\text { round }\end{array}$ & $?$ & $2: 1$ & $110-240$ & Parallel & $\begin{array}{l}\text { Schleich et al. } \\
\text { (1988) }\end{array}$ \\
\hline $\begin{array}{l}\text { Testudinarum } \\
\text { ovum }\end{array}$ & $\begin{array}{l}\text { Paleocene } \\
\text { Miocene }\end{array}$ & Germany & $\begin{array}{l}\text { Rigid/ } \\
\text { round }\end{array}$ & $?$ & $2: 1$ & $50-130$ & Parallel & $\begin{array}{c}\text { Schleich and Kästle } \\
\text { (1988), Schleich et } \\
\text { al. (1988) }\end{array}$ \\
\hline Unnamed & Oligocene & USA & Rigid & $43 \times 47$ & $?$ & $?$ & $?$ & $\begin{array}{c}\text { Hay (1908), Hirsch } \\
\text { and Bray (1988), } \\
\text { Hirsch (1996) }\end{array}$ \\
\hline Unnamed & Miocene & Venezuela & Rigid/elliptical & $43.5 \times 56.5$ & $5: 3$ & $565-730$ & Flared & $\begin{array}{c}\text { Winkler and } \\
\text { Sánchez-Villagra } \\
\text { (2006) }\end{array}$ \\
\hline
\end{tabular}

* Calculate shell unit height-to-width ratio by the description of the reference (Isaji et al. 2006). 
Emydoolithus laiyangensis is the second turtle egg fossil found in China. It differs from other chelonian egg fossils, which are round, while the oospecies here described presents an elliptical shape. Thus, it is represents a new type of turtle oospecies. Also, the discovery of this new turtle oospecies indicates that the Laiyang ecosystem in Late Cretaceous was thriving and more diverse than previously thought.

\section{ACKNOWLEDGMENTS}

We thank Cheng Xin, Li Yan, Xiang Long, Pan Rui, Shou Hua-quan, Gao Wei, Zhang Jie, Liu Xinzheng (Institute of Vertebrate Paleontology and Paleoanthropology, Chinese Academy of Sciences), Wang Jian-hua (Laiyang) for help in the field work. We thank Wang Hong for specimen preparation, Gao Wei for photos, and Zhang Wen-ding for SEM photos. We also thank De-Sui Miao (Natural History Museum and Biodiversity Research Center, University of Kansas, Lawrence, USA) and two anonymous reviewers for their valuable comments and English correction on the manuscript. This work was supported by the National Science Foundation of China (41172018), the National Science Fund for Distinguished Young Scholars (40825005), National Key Basic Research Program of China (973 Program) (2012CB821900), Key Laboratory of Evolutionary Systematics of Vertebrates, IVPP, CAS (2011LESV004), and local government special fund from Laiyang.

\section{RESUMO}

Uma nova espécie de ovo de tartaruga fóssil foi estabelecida: Emydoolithus laiyangensis oogen. et oosp. nov. Esta possui forma elíptica, uma casca rígida e outras características da casca que diferem dos demais ovos fósseis de quelônios conhecidos, todos de forma arredondada. Trata-se da segunda espécie de ovo fóssil de quelônio encontrado no Cretáceo na China. Esta descoberta mostra que o ecossistema Laiyang no Cretáceo Superior é mais diversificado do que se pensava.
Palavras-chave: ovo fóssil de tartaruga, Formação Jingangkou, Cretáceo Superior, Bacia Laiyang, Província de Shandong.

\section{REFERENCES}

Azevedo SA, Gallo V and Ferigolo J. 2000. A possible chelonian egg from the Brazilian Late Cretaceous. An Acad Bras Cienc 72(2): 187-193.

BRAY ES AND HIRSCH KF. 1998. Eggshell from the Upper Jurassic Morrison Formation. Modern Geol 23: 219-240.

CHOW MM. 1954. Cretaceous turtles from Laiyang, Shantung. Acta Paleont Sin 2: 395-408.

FANG XS, LU LW, JIANG YG AND YANG LF. 2003. Cretaceous fossil eggs from the Tiantai basin of Zhejiang, with a discussion on the extinction of dinosaurs. Geol Bull China 22(7): 512-520 (in Chinese).

HAY OP. 1908. The fossil turtles of North America. Carnegie Institution of Washington 75: 1-568.

HIRSCH KF. 1983. Contemporary and fossil chelonian eggshells. Copeia, p. 382-397.

HIRSCH KF. 1996. Parataxonomic classification of fossil chelonian and gecko eggs. J Vert Pal 16: 752-762.

HIRSCH KF AND BRAY ES. 1988. Spheroidal eggs - avian and chelonian - from the Miocene and Oligocene of the western interior. Hunteria 1(4): 1-8.

Hu CZ, Cheng ZW, PANG QQ AND FAng XS. 2001. Shantungosaurus giganteus. Beijing: Geological Publishing House, p. 71-111.

ISAJI S, MATSUSHITA A AND HIRAYAMA R. 2006. Chelonian eggshells from the Lower Cretaceous Kuwajima Formation of the Tetori Group, Central Japan. Paleont Res 10(1): 29-36.

JACKSON FD, JIN XS, VARRICCHIO DJ, AZUMA Y AND JIANG YG. 2008. The first in situ turtle clutch from Cretaceous Tiantai Basin, Zhejiang Province, China. J Vert Pal 28: 319-325.

JACKSON FD, SCHWEITZER MH AND SCHMITT JG. 2002. Dinosaur eggshell study using scanning electron microscopy. Scanning 24: 217-223.

KOHRING R. 1999. Strukturen, biostratiomie, systematische und phylogenetische Relevanz von Eischalen amnioter Wirbeltier. Couier Forschungsinstitut Senckenberg 210: 1-307.

LiU YQ, KuAng HW, Peng N, Xu H And LiU YX. 2011. Sedimentary facies of dinosaur trackways and bonebeds in the Cretaceous Jiaolai Basin, eastern Shandong, China, and their paleogeographical implications. Earth Sci Front 18(4): 9-24.

MikHAILOV KE. 1991. Classification of fossil eggshells of amniote vertebrates. Acta Palaeont Pol 36: 193-238.

MIKHAILOV KE. 1997. Fossil and recent eggshell in amniotic vertebrates: fine structure comparative morphology and classification. Special Papers in Palaeontology 56: 1-80. 
Mikhailov KE, Sabath K AND KuRZanov S. 1994. Eggs and nests from the Cretaceous of Mongolia; p. 137-150 in Carpenter K, Hirsch KF and Horner JR (Eds), Dinosaur Eggs and Babies. Cambridge University Press, New York.

MoHABEY DM. 1998. Systematics of Indian Upper Cretaceous dinosaur and chelonian eggshells. J Vert Pal 18: 348-362.

SCHLEICH HH AND KäSTLE W. 1988. Reptile Egg-shells SEM Atlas. Gustav-Fischer Verlag, Stuttgart, 128 p.

SCHLEICH HH, KÄSTLE W AND DYCK M GROESSENS-VAN. 1988. Paläogene Eischalenreste von Hainin (Belgien). Palaont Zeitschrift 62: 133-146.

WANG XL, WANG Q, JiAng SX, ChENG X, Zhang JL, ZHAO ZK AND JiANG YG. 2012. Dinosaur egg faunas of the Upper Cretaceous terrestrial red beds of China and their stratigraphical significance. J Stratig 36(2): 400-416.
Wang XL, Wang Q, Wang JH, Zhang JL, Cheng X, JIANG SX AND PAN R. 2010. An overview on the Cretaceous dinosaurs and their eggs from Laiyang, Shandong Province, China. In: Dong W (Ed), Proceedings of the Twelfth Annual Meeting of the Chinese Society of Vertebrate Paleontology, Beijing, OceanPress, p. 293-306.

WINKLER JD AND SÁNCHEZ-VILlAGRA MR. 2006. A nesting site and egg morphology of a Miocene turtle from Urumaco, Venezuela: evidence of marine adaptations in Pelomedusoides. Palaeontology 49: 641-646.

YABE H AND OzAKI KE. 1929. Fossil Chelonian (?) eggs from South Manchuria. Proceedings of the Imperial Academy 5(1): 42-45. 